\title{
Urban water supply and the changes in the precipitation patterns in the metropolitan area of São Paulo - Brazil
}

\author{
Gabriela Narcizo de Lima $^{\mathrm{a}, *}$, Magda Adelaide Lombardo ${ }^{\mathrm{b}}$, V. Magaña ${ }^{\mathrm{a}}$ \\ ${ }^{a}$ Instituto de Geografía (Institute of Geography), Universidad Nacional Autónoma de México/UNAM - Investigación Científica S.N., Ciudad Universitaria, 04510, Mexico \\ City, Mexico \\ ${ }^{\mathrm{b}}$ Instituto de Geociências e Ciências Exatas (Institute of Geosciences and Exact Sciences), Universidade Estadual Paulista "Julio de Mesquita Filho"/UNESP, Avenida 24 A, \\ 1515, 13506-900, Rio Claro, SP, Brazil
}

A R T I C L E I N F O

\section{Keywords:}

Metropolitan area of Sao Paulo

Rainfall

Water supply

Urban climate

\begin{abstract}
A B S T R A C T
The Metropolitan Area of Sao Paulo presents today one of the most critical situations in Brazil with regard to ensuring sufficient water supply in quantity and quality to its population. Declining water resources coupled with increased demand for clean water has already become a political issue in many localities. This study aimed to examine whether climate changes (especially in rainfall) resulting from the urbanization process are related to the urban water supply problems detected in the MASP, or whether they are due to poor management and the rapid growth of cities. Broadly, what can be concluded from the results of this research is that they indicate that there are signs of urbanization effects on the behavior of rainfall in the MASP. It was also identified that the averages of the volumes stored in the reservoirs that supply the MASP did not have a default behavior, even in similar weather conditions, suggesting the need for improvements in the systems.
\end{abstract}

\section{Introduction}

Created by the Complementary Law No. 14 of July 8, 1973, the Metropolitan Area of Sao Paulo (MASP) is composed of 39 municipalities, including the city of Sao Paulo (the state capital) and It is located at an altitude of approximately $750 \mathrm{~m}$ above sea level, with a large part of its territory in the Alto Tiete Basin within the Paulistano Plateau. According to the latest census (IBGE, 2011), the total population in the metropolitan area is 19,672,582 inhabitants.

The MASP presents today one of the most critical situations in the country with regard to ensuring sufficient water supply in quantity and quality for its population (Lima, 2015). Declining water resources coupled with increased demand for clean water has already become a political issue in many localities. This situation is becoming more and more aggravated by the constant urban expansion that generates the occupation of peripheral spaces and environmental protection areas, where are located drainage headwaters and important water bodies.

Currently, in the MASP the water supply is carried out in an integrated way that basically uses surface water sources, and consists of eight complexes (Cantareira, Guarapiranga, Rio Grande - Billings, Rio Claro, Ribeirao de Estiva, Alto Cotia, Baixo Cotia and Alto Tiete) that are responsible for the production of 67 thousand liters of water per second, to supply 32 municipalities served by the Companhia de
Saneamento Básico do Estado de Sao Paulo (SABESP) (Basic Sanitation Company of the State of Sao Paulo) and seven others that buy water wholesale (Santo André, Sao Caetano do Sul, Guarulhos, Mogi das Cruzes, Diadema, Santa Isabel and Mauá).

In the evaluation carried out by the Agência Nacional de Águas (ANA) (National Water Agency), almost all the producer systems, except for the Ribeirao de Estiva, require extensions or improvements to ensure the water supply to the MASP in the coming years.

Faced with this situation, in which the disorderly urban growth and increasing demand for water finds with obsolete supply systems that urgently need improvements to meet the population of the metropolis in the coming years, it is also important to discuss the issue of climate change (in particular precipitation regimes), which has been largely ignored by the authorities.

The MASP is located along a climatic transition range $\left(23^{\circ} 21^{\prime} \mathrm{S}\right.$ and $46^{\circ} 44^{\prime}$ W) between high-altitude Tropical Climate, with a defined dry period, and those subtropical, permanently humid in southern Brazil.

The combination of humid oceanic winds with the frontal positioning of the Planaltina escarpment and the crystalline mountains (beyond Tiete) favors the spatial variability of the precipitation in the MASP (Fig. 1). The Tiete valley is the area with the lowest precipitation rates, as well as the highest evapotranspiration losses, becoming the warmest and least humid part of the Alto Tiete Basin.

\footnotetext{
* Corresponding author. Investigación Científica S.N., Ciudad Universitaria, 04510, Mexico City, Mexico.

E-mail addresses: gabrielanl@gmail.com, glima@igg.unam.mx (G.N.d. Lima).
} 


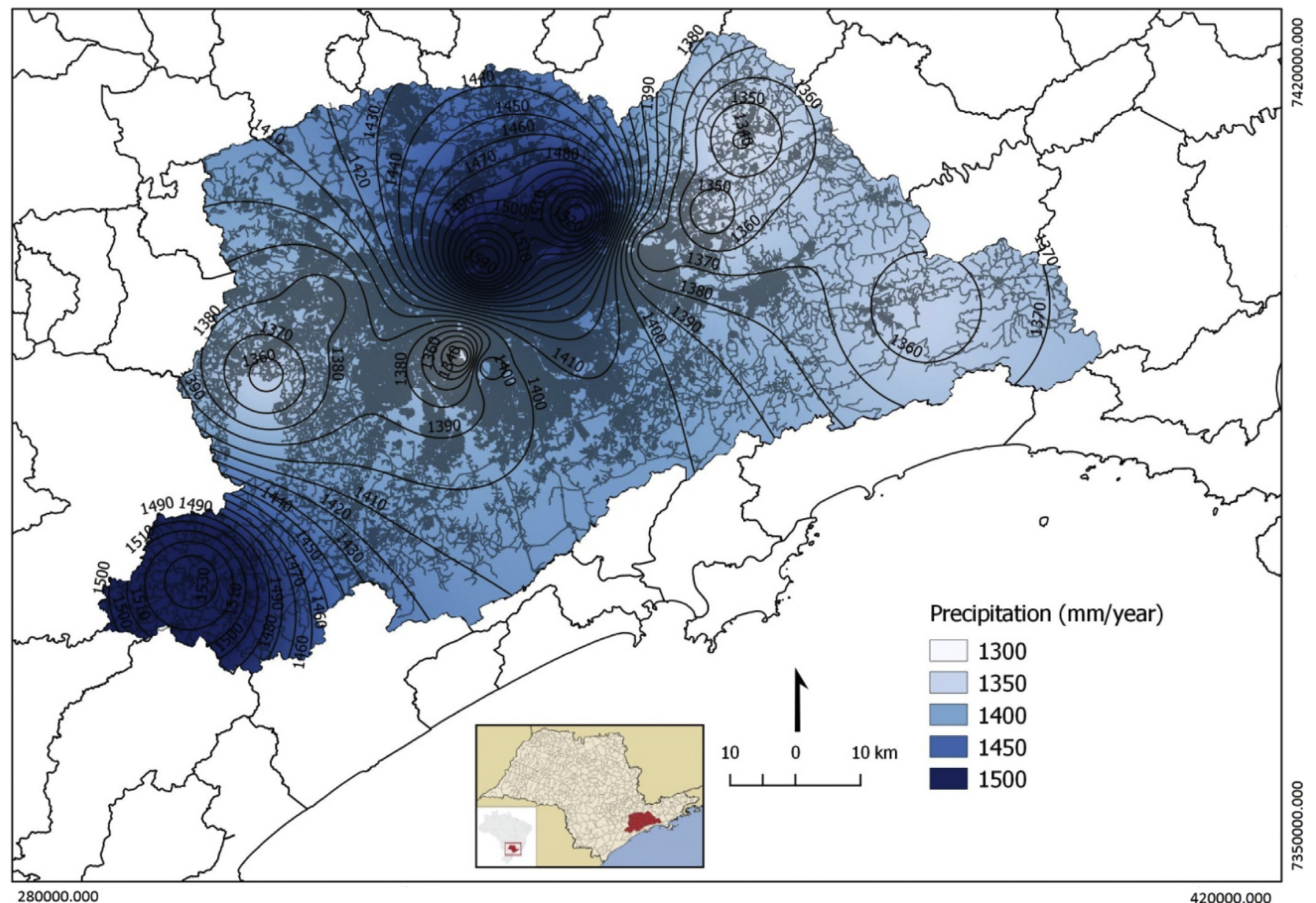

Fig. 1. Average annual rainfall in the MASP (1933-2014).

In the MASP, precipitation systems of convective origin are the most representative and are attributed to topography, surface characteristics, the injection of moisture brought by the sea breeze and the existence of Islands of Heat.

The increasing urbanization, acting in synergy with the temperature increase, presents potential for the occurrence of events with intense precipitation increasingly frequent, especially considering the tendency for the next decades of a pattern of urban growth in the metropolis similar to the current one in which the quality of life, the environment and the sustainable future of natural resources are ignored.

However, the episodes of higher rainfall are not well distributed throughout the year. Sant'anna Neto (1995) verified a generalized increase of precipitation in several cities of the state of Sao Paulo, with higher concentrations in the spring/summer, that is, the rainfall increment did not occur uniformly in the different seasons of the year, on the contrary, they were higher from October to March. The author also noted that the dry season, which used to be concentrated between April and September, in most of the state, has lasted until October in the last decades.

It is considered that the urban supply systems in the MASP are not prepared to adequately serve the population, given the problems presented, namely, the disorganized occupation of areas of environmental protection, and the trends of changes in the rainfall regime in urbanized areas, which will worsen in the coming decades.

- Thus, the main objective of this work is to demonstrate that the problems of water supply in the MASP are not due to the reduction of annual rainfall, as the media often says, but in the absence of an adequate planning to face the new rain patterns, in which the dry season is prolonging while in the summer months occur more intense precipitations.

\section{Materials and methods}

Analysis of trends and climate variability was carried out using the climatic data of seven (07) pluviometric stations distributed by the MASP (ANA, 2017) and three (03) meteorological stations monitored by the National Institute of Meteorology (INMET, 2017) (Table 1), both seasonally and yearly, from daily and monthly values. It was sought to obtain long series, with at least 30 years of data and that had records until the year 2015 .

Information on urban water supply comes from government agencies such as the ANA, the Departamento de Águas e Energia Elétrica (Water and Electrical Energy Department) and the SABESP.

For the analysis of the annual behavior of precipitation classes, the hydrological year was considered (August to July), to include the entire rainy season, which in the Southeast region runs from September to March. Regarding the seasonal behavior, the quarters for each season were considered, with emphasis on the January, February, and March (summer) analyses, which are the rainiest months in the region.

The daily precipitations of the 10 stations were classified into three categories: light rain, with totals between $0.1 \mathrm{~mm} /$ day and $5 \mathrm{~mm} /$ day, moderate, with totals between $10 \mathrm{~mm} /$ day and $30 \mathrm{~mm} /$ day and severe or intense, with totals higher than $30 \mathrm{~mm} /$ day. For each hydrological year and summer period, the case numbers were computed for each of the three categories of precipitation considered. These annual and seasonal series of the number of events of light rainfall, moderate and intense precipitation were submitted to Mann-Kendall (MK) trend tests, 
Table 1

Meteorological and pluviometric stations.

\begin{tabular}{|c|c|c|c|c|c|c|}
\hline \multicolumn{7}{|c|}{ Meteorological stations and pluviometric stations } \\
\hline Station name & Municipality & Station code & Altitude & Latitude & Longitude & Period of data \\
\hline FAZENDA SAO BENTO & ARUJÁ & 2346029 & 690 & $23^{\circ} 26^{\prime}$ & $46^{\circ} 17^{\prime}$ & $1962-2015$ \\
\hline SANTA ISABEL & SANTA ISABEL & 2346019 & 690 & $23^{\circ} 20^{\prime}$ & $46^{\circ} 14^{\prime}$ & $1941-2015$ \\
\hline PONTE NOVA & SALESÓPOLIS & 2345049 & 800 & $23^{\circ} 34^{\prime}$ & $45^{\circ} 58^{\prime}$ & $1967-2015$ \\
\hline MONTE BELO & ITAQUAQUECETUBA & 2346040 & 790 & $23^{\circ} 29^{\prime}$ & $46^{\circ} 22^{\prime}$ & $1943-2015$ \\
\hline JUQUITIBA & JUQUITIBA & 2347051 & 680 & $23^{\circ} 56^{\prime}$ & $47^{\circ} 04^{\prime}$ & $1947-2015$ \\
\hline CACHOEIRA DA GRAÇA & COTIA & 2346052 & 880 & $23^{\circ} 39^{\prime}$ & $46^{\circ} 57^{\prime}$ & $1936-2015$ \\
\hline BAIXO COTIA & BARUERI & 2346002 & 730 & $23^{\circ} 33^{\prime}$ & $46^{\circ} 52^{\prime}$ & $1937-2015$ \\
\hline MIRANTE DE SANTANA & SAO PAULO & 83781 & 792 & $23^{\circ} 30^{\prime}$ & $46^{\circ} 37^{\prime}$ & $1961-2015$ \\
\hline GUARULHOS & GUARULHOS & 83075 & 765 & $23^{\circ} 26^{\prime}$ & $46^{\circ} 28^{\prime}$ & 1983-2015 \\
\hline IAG & SAO PAULO & 83004 & 800 & $23^{\circ} 37^{\prime}$ & $46^{\circ} 39^{\prime}$ & $1933-2015$ \\
\hline
\end{tabular}

considered to be one of the most suitable for detecting climatic trends (Goossens \& Berger, 1986).

The MK test consists of comparing each value of the time series with the remaining values in their sequential order. It is based on the reduced normal distribution $\mathrm{z}$ of the variable $\mathrm{t}$, which is the sum of the previous cases in the series that are inferior to it:

$z(t)=(t-E)) / \sqrt{ } \operatorname{var}(t)$

In which the mathematical expectation $\mathrm{E}(\mathrm{t})$ and the variance var $(\mathrm{t})$ are, according to Sneyers (1975), given by:

$E(t)=n(n-1) / 4$

$\operatorname{var}(t)=n(n-1)(2 n+5) / 72$

The MK test also allows us to identify the direction of the trend through the sign of $\mathrm{z}(\mathrm{t})$ and its beginning, through its progressive application, as shown in Sneyers (1975). For the series with significant trends in the confidence level adopted (95\%, with $|z|>1.96)$, their linear trends were obtained using regression by the least squares method.

Taking the series of climate data with the least amount of missing data and a significant trend in the confidence level adopted as desirable (IAG), a comparison was made with the indices of the water volumes stored in the reservoirs that supply the MASP calculated from the data provided by SABESP since 2003 and including air temperature, evapotranspiration, total flow and daily withdrawal (Lima et al., Data in Brief), to identify if the precipitation tendencies found can influence the water levels stored in the reservoirs in a way that harms the water supply to the region.

It is important to mention that there are eight water-producing systems, but due to information protection issues, SABESP only discloses data from six of them (Cantareira, Alto Tiete, Guarapiranga, Alto Cotia, Rio Grande - Billings e Rio Claro).

\section{Results and discussion}

\subsection{Meteorological data analysis}

The rapid growth of the urban centers of Latin America during the twentieth century that generated the so-called megacities has led to an increase in climate risk, not always attended to by the authorities. With the urban expansion the natural environment is modified and with it the climate, including its extreme conditions.

Unplanned urbanization often increases exposure to weather hazards with vulnerable structures and a more vulnerable population. Thus, the increased danger and vulnerability generate a greater climate risk that is often materialized in more frequent and costly disasters. Therefore, adequate risk management in the area of Civil Protection, water management or human health requires adequate characterization, not only of urbanization processes, but also of those that alter the climate, and the way in which they induce greater climate vulnerability in the population.

Of the climatic parameters that are affected by the process of urbanization, perhaps the increase of the temperature is best known, by the formation of the Urban Heat Islands (UHI). But such a process of warming in the lower part of the atmosphere has impacts on atmospheric humidity, human comfort conditions, the atmospheric stability that allows the development of deep clouds, and therefore in the occurrence of intense rain events or in the lack of them.

Liebmann et al. (2004) showed that the south-central region of Brazil presented between 1976 and 1999, significant linear trends of summer precipitation $(7.5 \mathrm{~mm} / \mathrm{summer})$, and also positive but much smaller $(2.7 \mathrm{~mm} /$ summer) between 1948 and 1975. The authors attributed this increase in rainfall to an intensification in the number of rainy days associated with a rise in the surface temperatures of the adjacent Atlantic. It is observed that these two periods analyzed 1976-1999 and 1948-1975 are, respectively, coincident with a warm and a cold phase of the Pacific Decadal Oscillation (PDO).

Carvalho et al. (2002, 2004) observed that extreme precipitation events in the State of Sao Paulo are associated with the intensity of the South Atlantic Convergence Zone and the convective activity linked to the Madden-Julian Oscillation. The authors also observed that extreme precipitation events in southeastern Brazil exhibit interannual variability related to large-scale forcing, with more extreme events under El Niño than La Niña conditions.

The frequency and intensity of precipitation in the south and southeast of Brazil, especially the severe and extreme ones, are also influenced by the surface temperatures of the Pacific Ocean in the interannual and decadal scales. El Niño/Southern Oscillation (ENSO) is the dominant mode of global interannual climatic variability, which in turn is associated with PDO. Generally, the positive or hot phases of the PDO are associated with a higher frequency of El Niño events and intense precipitation in the region, while the negative or cold phases with more occurrences of La Niñas and scarce precipitations (Molion, 2005). In the State of Sao Paulo, the interannual variability of the precipitations associated to the ENSO does not present a well-defined signal (Coelho, Uvo, \& Ambrizzi, 2002).

Haylock, Peterson, Abreu de Sousa, Alves, and others (2006), based on 40-year daily rainfall data (1960-1999) found an increase in the frequency and intensity of rainy days in southeastern South America. This trend would be associated with a shift to conditions dominated by El Niños.

Dufek and Ambrizzi (2008) analyzing daily rainfall data at 59 stations in the State of Sao Paulo between 1950 and 1999, observed a significant increase in annual totals, which would be associated with an increase in occurrences precipitations above $20 \mathrm{~mm} /$ day.

Increased rainfall extremes in recent decades may also be linked to the process of urbanization and UHI generation. Pereira Filho, Barros, Hallak, and Gandu (2004) and Xavier, Xavier, and Silva Dias (1994) showed that summer precipitation is increasingly intense in the MASP, 
due to the effects of the UHI associated with the circulation of the sea breeze. Xavier et al. (1994) found in the period from 1933 to 1986, an increase in the most intense precipitations in February and May and a reduction in rainfall below $5 \mathrm{~mm}$ /day all year.

In a decadal analysis of rain extremes for the IAG meteorological station between 1933 and 2010, Nobre, Young, Saldiva, Marengo, and others (2011) observed an increase of $40 \%$ in cases of precipitation higher than $30 \mathrm{~mm} /$ day, in addition to an increase in decennial frequency from 9 (1933-40) to $40(2000-2009)$ in precipitation events higher than $50 \mathrm{~mm} /$ day. Precipitations below $1 \mathrm{~mm} /$ day (drizzle) presented a decrease, especially in the last 20 years, while those of higher volumes showed a constant increase.

The changes detected in the convective activity (development of deep clouds that generate abundant rainfall) are perhaps one of the most worrisome, because of the "water proofing" process that urbanization produces and that increases the risk of flooding.

In this work, considering the results of the MK tests for the annual values of precipitation, it was verified that seven of the ten series analyzed have a positive trend of increasing rainfall. The most significant values were recorded in the stations of the IAG and Mirante de Santana, and in the pluviometric station Fazenda Sao Bento, in agreement with the evaluation carried out by Marengo, Valverde, and Obregon (2013).

Fig. 2 shows a slight increase in rainfall totals from 1976, the transition period from the cold phase to the hot phase of the PDO. Most of the data series also showed this tendency in the annual totals, when compared to the cold phase of the PDO (1947-1976).

In the hydrological year 1982/1983, when a strong El Niño occurred, the largest accumulations were recorded in almost all series, but El Niño events are not the main ones responsible for the increase in accumulated totals in the region. In 1982/1983, the mechanism associated with the high volumes of precipitation recorded was an atmospheric blockage caused by the influence of an anticyclone that occurs in the high troposphere, in the summer, in South America named Alta da Bolívia.

Regarding the summer values (January to March), which is characterized as the rainy season in the RMSP, it was possible to notice that six of the ten data series analyzed showed positive trends of precipitation increase, four of them being well marked: IAG (Fig. 3), Cachoeira da Graça, Mirante de Santana and Fazenda Sao Bento.

During the autumn quarter (April to June), the data series of the IAG and Mirante de Santana meteorological stations and the Fazenda Sao Bento, Santa Isabel, Monte Belo and Cachoeira da Graça pluviometric stations showed again positive trends of precipitation increase, Repeating the pattern of the summer period.

The winter quarter (July to September), characteristically the least rainy for the region, presented five data series with positive trends for the increase of precipitation (Baixo Cotia, Cachoeira da Graça, Santa Isabel, IAG and Mirante de Santana). Four series with a null tendency (Monte Belo, Fazenda Sao Bento, Guarulhos, and Juquitiba) and one with a negative trend (Ponte Nova).

Finally, the series related to the spring, which runs from October to December and is characterized by the gradual increase of rainfall and temperatures in relation to winter, did not show any negative trend, five of them with positive trends (Guarulhos, Mirante de Santana, IAG, Santa Isabel and Baixo Cotia) and the others with null trends (Juquitiba, Fazenda Sao Bento, Monte Belo, Cachoeira da Graça and Ponte Nova).

It is interesting to note that most of the data series with positive trends of precipitation increase are found in densely urbanized areas of the RMSP, and even when the collection point of the station is located in a green area, as is the case of the meteorological station of the IAG, it is possible to perceive that the surrounding environment is characterized as an urban area.

\subsection{Analysis of the storage volumes of the reservoirs of the MASP}

In order to perform the analysis of the storage volumes of the reservoirs supplying the MASP, the data provided daily by SABESP (2017) were used (with records available from 2003), including data on air temperature, evapotranspiration, total flow and daily withdrawal.

The average annual precipitation in the region is between $1300 \mathrm{~mm}$ and $1500 \mathrm{~mm}$, and rainfall provides $90-95 \%$ of the water in the basin. However, although the general tendency of meteorological data is that there is an increase in precipitation totals, some of the reservoirs are under great pressure, since they serve a great number of the metropolitan population, besides commercial uses, that between 2005 and 2014 increased 92 times its demand for water, reaching a total of 25 billion liters of water consumed per year.

The water supply in the MASP is carried out by the Sistema Adutor Metropolitano (Metropolitan Aqueduct System), which is the interconnection of all producer systems, in which mainly surface water sources are used.

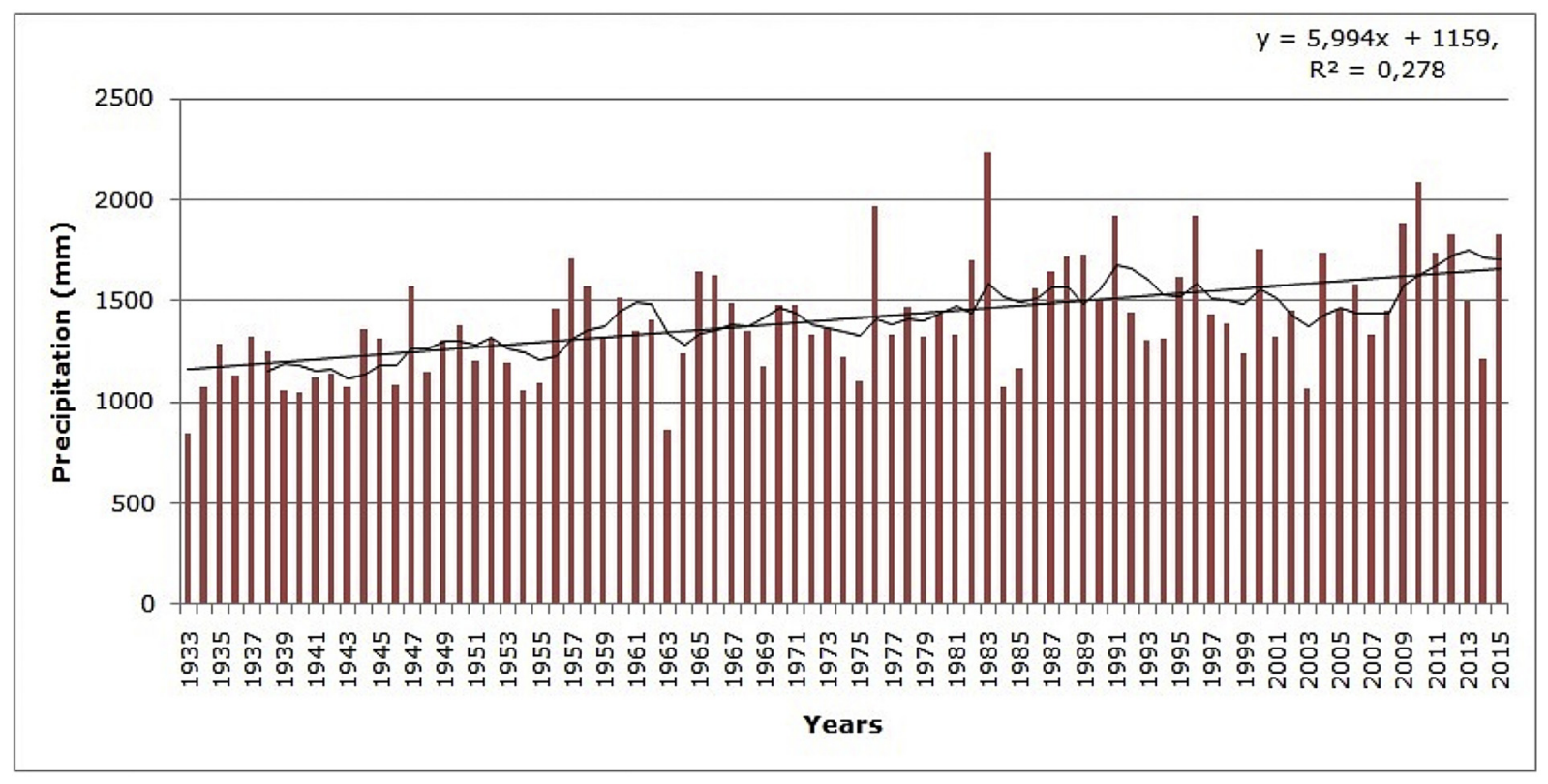

Fig. 2. Total annual rainfall (mm/year) - IAG (1933-2015). 


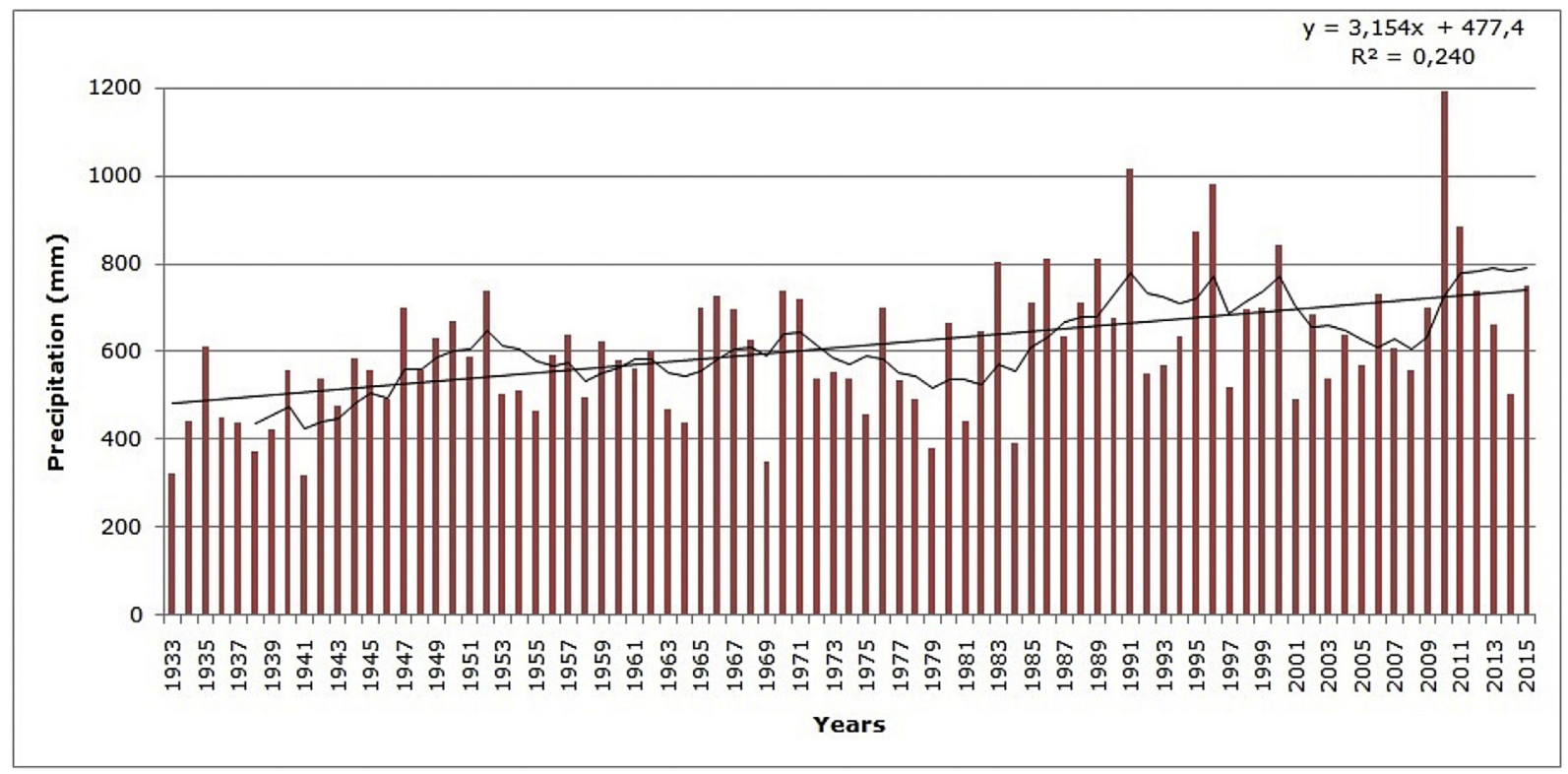

Fig. 3. Precipitation (mm) - Summer IAG (1933-2015).

The volumes of water stored in the reservoirs are controlled daily by measurements, and the values reported refer to the total stored in the "Useful Volume", which is the one that can be used without the need for pumping, plus the "Technical Reserve", stocked volume in the reservoir which can only be used with the aid of pumping.

Initially, the seasonal values of the storage volumes of the sources were analyzed. The summer trimester (Fig. 4), commonly the rainy season in the region, presented periods of very low volumes, to the detriment of rainfall precipitation totals. Especially in the reservoirs of Cantareira and Alto Tiete, which presented great oscillations over the years.

Special emphasis is given to the summer of 2004, when rainfall totals exceeded $600 \mathrm{~mm}$, while volumes stored in the reservoirs of Cantareira, Alto Tiete, Alto Cotia and Guarapiranga did not reach $40 \%$ of their capacity. The most serious case is that of Cantareira, which recorded averages of $9.2 \%$ of storage in this period, with some days presenting values below $4 \%$.
During the autumn quarter, the storage volumes of the MASP reservoirs showed a slight increase, due to the accumulation of summer rains. Again, the year 2004 stands out, as the sources of Cantareira, Alto Tiete, Guarapiranga and Alto Cotia remained with low average volumes, slightly larger than those recorded in the previous quarter.

The year 2012 also calls attention, because even with a cumulative rainfall of more than $1000 \mathrm{~mm}$ in the summer and autumn quarters, the reservoir of the Alto Tiete System presented an average volume of just over $50 \%$ of its total capacity.

In the winter quarter, with decreasing rainfall, storage totals of all reservoirs fell slightly, but it is interesting to note that volumes recorded in the Rio Grande System fluctuated less, always remaining near their maximum capacity. During spring, precipitation totals increased somewhat relative to winter, and consequently the volumes stored in the reservoirs.

The Cantareira and Alto Tiete Systems are the most unstable, suffering falls in volumes stored quickly, even when the rainfall totals

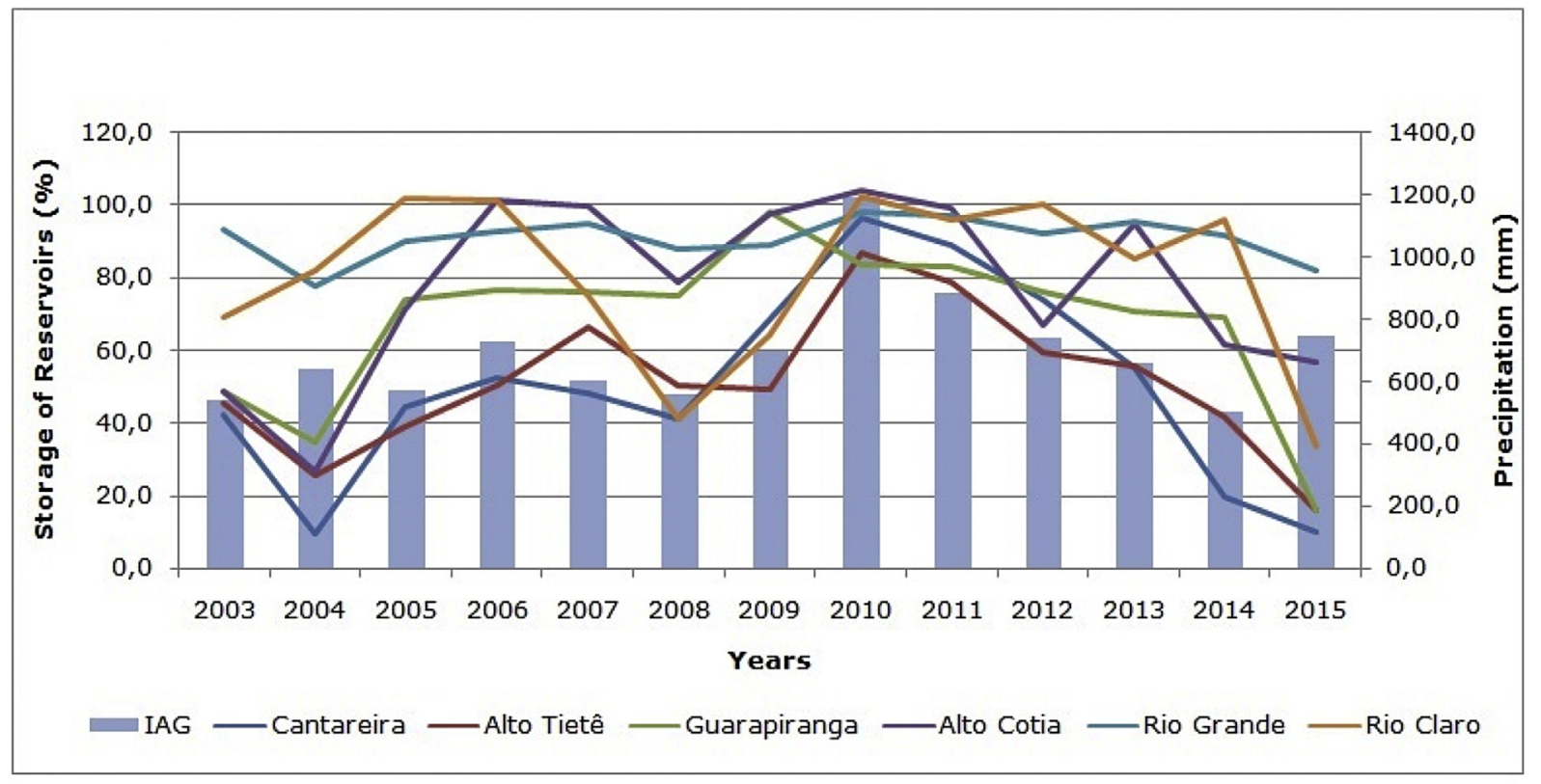

Fig. 4. Volumes stored in MASP water reservoirs - Summer (2003-2015). 


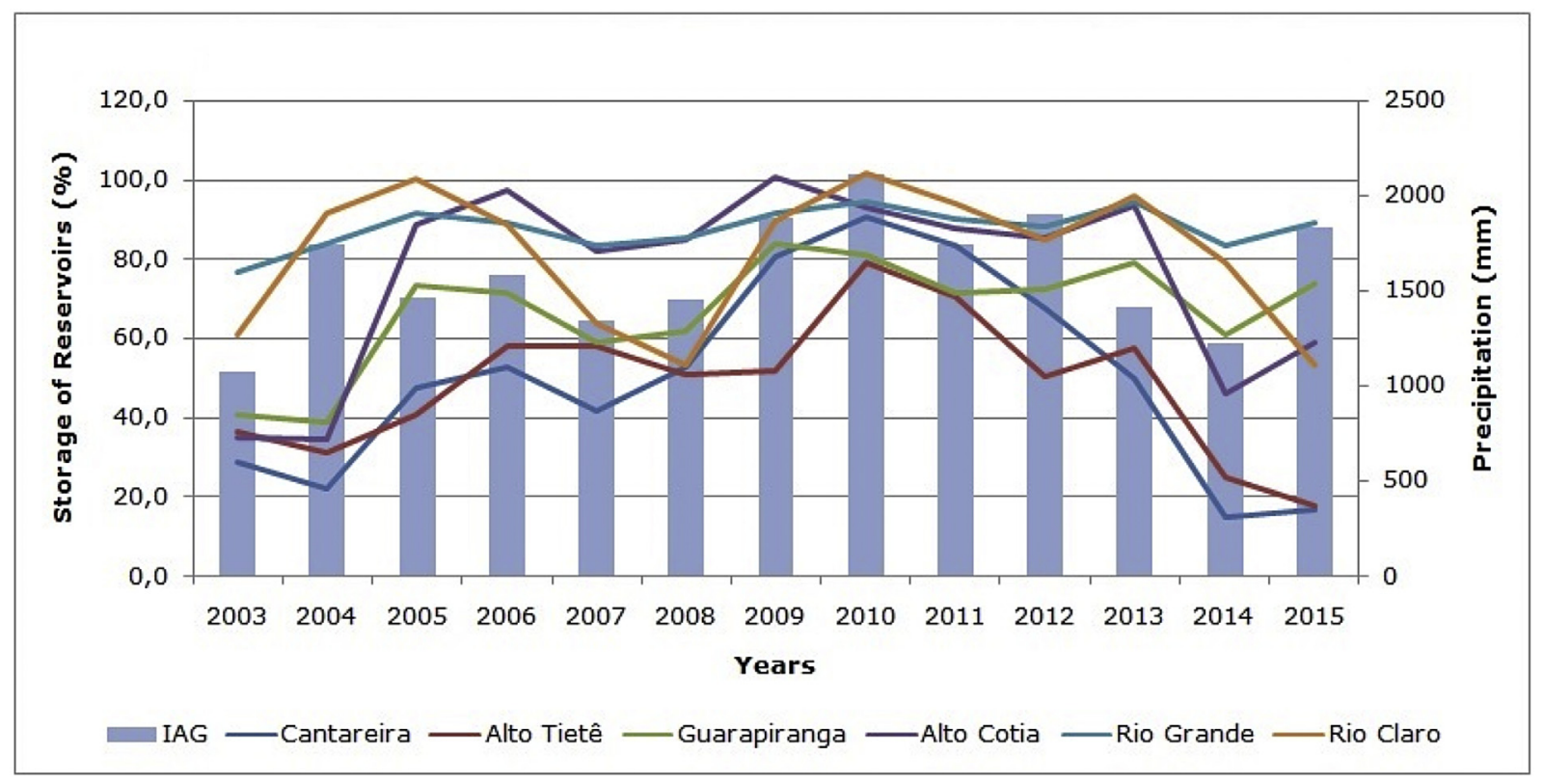

Fig. 5. Annual volumes stored in MASP water reservoirs (2003-2015).

remain within the normal averages for the period. While the Rio Grande System reservoir at no time presented average volumes below $60 \%$ of its capacity, the Cantareira, Alto Tiete, Guarapiranga and Alto Cotia Systems presented volumes that oscillated rapidly reaching critical values, such as 4, 8\% (Cantareira, 2003) and 7.9\% (Alto Cotia, 2003).

Looking at the graph with mean annual storage values (Fig. 5), it is possible to have a broader view of the behavior of each reservoir.

Under similar climatic conditions, the storage rates of each reservoir are quite different, suggesting that precipitated rainfall totals are not the only factor causing the MASP supply problems, and the most notable examples are the Cantareira and Alto Tiete Systems in comparison with the Rio Grande System.

Often the public power and the media attribute the problems of water scarcity to declining rainfall over some years, but analysis of data on precipitation totals and storage volumes of water sources indicates that this is not a simple matter, and certainly involves many other factors, such as the lack of investments in works to improve supply systems, plant loss in the vicinity of reservoirs resulting from urban sprawl, among others.

Research conducted in different cities in the United States (Chang, Praskievcz, \& Paeandvash, 2014), Czech Republic (Vizina, Hanel, Kozín, \& Horácek, 2015), Mexico (Gómez, Austria, Romero, Monroy, \& Polo, 2015), Spain (Arribas, Beas, \& Sáez, 2015) and Nigeria (Umar, 2015) found similar results, using several models, in which the precipitation variable always had a central role.

In all cases, the impacts that climate change has on water management have been analyzed, either in the river basins as a whole or in the supply reservoirs. The future scenarios presented are worrying and require immediate adaptations in supply systems to maintain water availability in the coming decades.

\section{Conclusions}

The annual and seasonal precipitation increase trends found in most of the series analyzed in this research indicate that there is a causality related to the high atmospheric pollution levels recorded in the large metropolises, the intensification of the UHI and the roughness effect, resulting from the verticalization process.

In addition to the current research, urbanization and UHI also led to total precipitation increasing in upstream and downstream directions of major cities, including Atlanta, Dallas, San Antonio and Nashville in the
USA (Shepherd, Pierce, \& Negri, 2002) and in Beijing, China (Yu \& Liu, 2015), which is good in terms of water quantity. However, UHIs can impair water quality of natural waterways since hot pavement and rooftop surfaces transfer their excess heat to storm water and can raise water temperatures of receiving streams, rivers, ponds, and lakes. For example, increased urban water body temperatures due to UHI caused a decrease in aquatic diversity and fish kills in the streams tributary of Onondaga Lake, New York (Smith, Abele, Heitzman, \& Duffy, 2008).

It is important to emphasize that besides the influence of UHI, phenomena of regional and global scale, such as the occurrences of the El Niño phenomenon and variations in the surface temperature of the Atlantic Ocean, also contribute to generating positive trends of increase in rainfall totals.

By analyzing the data related to the storage of the water sources, it is noticed that the averages of the volumes stored in the reservoirs that supply the MASP did not present a standard behavior. Even in similar climatic conditions, some reservoirs had a high volume of stored water, While others oscillated rapidly, often exhibiting values well below their capacity. The most emblematic cases are those of the Cantareira and Alto Tiete Systems, which at times reached very low volumes, less than $10 \%$ of their total capacity.

Contrary to what has occurred with the Cantareira and Alto Tiete Systems, the Rio Grande System reservoir has been presented throughout the analysis with high stored volumes, even in years with below-average rainfall, which indicates that rainfall totals are not the only factors causing supply problems in the MASP.

Considering that the analysis of the precipitation data presented here demonstrates a positive trend of increase in rainfall totals, this would not be a problem to be considered for the future, nevertheless, there is need for the improvement in the water system to take advantage of the increasing water availability via the following ways: i) by developing hydro-basins and transferring water from areas in which it is abundant to areas in which there is scarcity, ii) by increasing storage capacity by building reservoirs and dams, iii) by harvesting rainwater in new and old buildings in the cities; iv) by use of recycled/ reclaimed/stormwater water for landscape irrigation or to recharge groundwater aquifers, or to meet commercial and industrial water needs (Kibria, Haroon, \& Nugegoda, 2016).

From the legal point of view, there are already some laws that dictate conditions for the adequate use of the reservoirs for purposes of public supply and the disciplining of the use of the soil for protection of 
water resources, such as Law No. 1172/1976, Decree No. 9.714/1977 and Law No. 9.866/1997, however, what is observed is the constant growth of the urban area of the MASP towards the protected areas and the non-compliance of these norms even by the public power.

Irregular occupation of protected areas dramatically affects water quality and directly influences the availability of this resource to supply a population that is constantly growing.

\section{Funding}

This work was supported by the "Dirección general de asusntos del personal académico - UNAM/DGAPA".

\section{Acknowledgments}

We are grateful to the "Center for Environmental Analysis and Planning- UNESP/Rio Claro" and the "Institute of Geography - UNAM" for making this work possible.

\section{References}

ANA (Agencia Nacional de Águas) (2017). Pluviometric stations. Available at: http:// hidroweb.ana.gov.br (Accessed 0303 2016).

Arribas, E. C., Beas, R. G., \& Sáez, A. L. (2015). Smart water management in complex basins through integrated decisions support technologies. In J. A. Raynal - Villaseñor (Ed.). Facing the threat: Climate change (pp. 149-164). Puebla: UDLAP.

Carvalho, L. M. V., Jones, C., \& Liebmann, B. (2002). Extreme precipitation events in southern South America and large-scale convective patterns in the South Atlantic convergence zone. Journal of Climate, 15, 2377-2394.

Carvalho, L. M. V., Jones, C., \& Liebmann, B. (2004). The South atlantic convergence zone: Intensity, form, persistence, relationships with intraseasonal to interannual activity and extreme rainfall. Journal of Climate, 17, 88-108.

Chang, H., Praskievcz, S., \& Paeandvash, H. (2014). Sensitivity of urban water consumption to weather and climate variability at multiple temporal scales: The case of Portland, Oregon. International Journal of Geospatial and Environmental, 1. article 7. Available at: http://dc.uwm.edu/ijger/vol1/iss1/7.

Coelho, C. A. S., Uvo, C. B., \& Ambrizzi, T. (2002). Exploring the impacts of the tropical Pacific SST on the precipitation patterns over South America during ENSO periods. Theoretical and Applied Climatology, 71, 185-197.

Dufek, A., \& Ambrizzi, T. (2008). Precipitation variability in Sao Paulo state, Brazil. Theoretical and Applied Climatology, 93, 167-178.

Gómez, C. P., Austria, P. F. M., Romero, P. H., Monroy, R. M., \& Polo, D. E. G. (2015) Geographic information system: A useful tool for water management under climate change conditions. In J. A. Raynal - Villaseñor (Ed.). Facing the threat: Climate change (pp. 189-202). Puebla: UDLAP.

Goossens, C., \& Berger, A. (1986). Annual and seasonal climatic variations over the northern hemisphere and Europe during the last century. Annales Geophysicae, 4, 385-400.

Haylock, M. R., Peterson, T., Abreu de Sousa, J. R., Alves, L. M., \& others (2006). Trends in total and extreme South American rainfall 1960-2000 and links with sea surface temperature. Journal of Climate, 19, 1490-1512.

IBGE (Instituto Brasileiro de Geografía e Estatística) (2011). Sinopse do censo demográfico 2010. Available at: www.ibge.gov.br (Accessed 2508 2016).

INMET (Instituto Nacional de Meteorologia) (2017). Weather stations. Available at: http://www.inmet.gov.br (Accessed 0303 2016) .

Kibria, G., Haroon, A. K. Y., \& Nugegoda, D. (2016). Climate change and water security: Impacts, future projections, adaptations and mitigations. 978-93-85516-26-9320. http:// dx.doi.org/10.13140/RG.2.1.1848.1528/1.

Liebmann, B., Vera, C. S., Carvalho, L. M. V., Camilloni, I., Hoerling, M. P., Barros, V. R., et al. (2004). An observed trend in central South American precipitation. Journal of Climate, 17, 4357-4367.

Lima, G. N. (2015). O desafio da manutenção do abastecimento hídrico na região metropolitana de Sao Paulo: Busca por uma gestão sustentávelDoctoral Thesis. Faculdade de Filosofia, Letras e Ciências Humanas, Universidade de Sao Paulo.

Lima, G. N.; Lombardo, M. A. \& Magaña, V. O. Submitted for publication. Data on the volumes of water stored in the reservoirs supplying the Metropolitan Area of Sao Paulo (2003-2015). (Data in Brief).

Marengo, J. A., Valverde, M. C., \& Obregon, G. O. (2013). Observed and projected changes in rainfall extremes in the metropolitan area of Sao Paulo. Climate Research, 57, 61-72. http://dx.doi.org/10.3354/cr01160.

Molion, L. C. B. (2005). Aquecimento global, El Niños, manchas solares, vulcões e Oscilação Decadal do Pacífico. Climanálise. August. CPTEC/INPE).

Nobre, C. A., Young, A. F., Saldiva, P., \& Marengo, J. A. others. (2011). Vulnerabilidade das megacidades brasileiras ás mudanças climáticas: Região metropolitana de Sao Paulo. Sao Paulo: INPE/UNICAMP/USP/IPT/UNESP.

Pereira Filho, A. J., Barros, M. T. L., Hallak, R., \& Gandu, A. W. (2004). Enchentes na região metropolitana de Sao Paulo: Aspectos de mesoescala e avaliação de impactos. Fortaleza, CE (Anais CDROM): XIII CBMET.

SABESP (Companhia de Saneamento Básico do Estado de Sao Paulo) (2017). Data on water supply in MASP. Available at: www2.sabesp.com.br (Accessed 0508 2016) .

Sant' anna Neto, J. L. (1995). As chuvas no Estado de Sao Paulo. Doctoral Thesis. Faculdade de Filosofia, Letras e Ciências Humanas, Universidade de Sao Paulo.

Shepherd, J. M., Pierce, H., \& Negri, A. J. (2002). Rainfall modification by major urban areas: Observations from Spaceborne rain radar on the TRMM Satellite. Journal of Applied Metrology, 41, 689-701. http://dx.doi.org/10.1175/1520-0450(2002) $041<0689$ :RMBMUA > 2.0.CO; 2 .

Smith, A. J., Abele, L. E., Heitzman, D. L., \& Duffy, B. (2008). Streams tributary to Onondaga Lake biological assessment. Albany, New York: New York State Department of Environmental Conservation. http://www.dec.ny.gov/docs/water_pdf/ sbuondgatribs08.pdf.

Sneyers, R. (1975). Sur l'analyse statistique des séries d'observations. Gènéve: Organisation Météorologique Mondial (OMN, Note Technique 143).

Umar, A. T. (2015). Pattern of rainfall anomalies and rural water supply in SudanoSahelian Region of Nigeria. In J. A. Raynal-Villaseñor (Ed.). Facing the threat: Climate change (pp. 203-217). Puebla: UDLAP.

Vizina, A., Hanel, M., Kozín, R., \& Horácek, S. (2015). Bias correction methods for water resources management. In J. A. Raynal - Villaseñor (Ed.). Facing the threat: Climate change (pp. 135-147). Puebla: UDLAP.

Xavier, T. M. B. S., Xavier, A., \& Silva Dias, M. A. F. (1994). Evolução da precipitação diária num ambiente urbano: O caso da cidade de Sao Paulo. Rev Bras Meteorol, 9, 44-53.

Yu, M., \& Liu, Y. (2015). The possible impact of urbanization on a heavy rainfall event in Beijing. Journal of Geophysical Research, 120, 8132-8143. http://dx.doi.org/10.1002/ 2015JD023336. 